DOI mics2020.11.116

УДК 902/904

Олена Махота,

молодша наукова співробітниця науково-дослідного сектора археології,

Національний Києво-Печерський історико-культурний заповідник

makhota-olena@ukr.net

https://orcid.org/0000-0002-2742-4255

\title{
ДАВНЬОРУСЬКІ БУДІВЕЛЬНІ МАТЕРІАЛИ У ПОХОВАЛЬНИХ КОМПЛЕКСАХ ХVII-XIX СТ. НЕКРОПОЛЯ СПАСА НА БЕРЕСТОВІ (ЗА МАТЕРІАЛАМИ ДОСЛІДЖЕНЬ 2018-2019 рр.)
}

У статті розглянуто процес використання давньоруських будівельних матеріалів у поховальних конструкціях доби Модерну на некрополі церкви Спаса на Берестові. Визначено основні періоди дослідження Спаського некрополя від 1914 до 2019 рр.

За науковими звітами та публікаціями 1914-2003 рр. зібрано дані про поховання XII-XIX ст., що містили давньоруські будівельні матеріали: плінфу та плити пірофілітового сланцю. Основну увагу зосереджено на інформації, отриманій авторкою статті під час науково-рятівних досліджень у 2018-2019 рр., де було зафіксовано дев'ять поховань (XVII-XIX ст.) із частковим або повним огороджуванням небіжчика давньоруськими будівельними матеріалами. На сьогодні будівельні матеріали давньоруського періоду на території Спаського некрополя трапляються у вигляді частини поховальної конструкції, додаткових елементів у облаштуванні могили та у заповненні поховальних споруд. Зібраний та опрацьований комплекс матеріалів надає додаткові дані для реконструкції історичних подій, пов'язаних із занепадом та відбудовою церкви. Фіксування подібних поховальних конструкцій, своєю чергою, також надає непрямі дані про традиції поховального обряду мешканців Печерського містечка та військових Київської фортеці у XVII-XIX ст. - прихожан церкви Спаса на Берестові.

Ключові слова: поховальна конструкція, будівельні матеріали, плінфа, некрополь, церква Спаса на Берестові, доба Модерну. 
1 Твакін, В. (2008). Християнські поховальні пам'ятки давньоруського Києва. Київ: КИТ; Мельник, О. (2017). Поховальні пам'ятки Києва XVI-XVIII cm. (Дис. канд. іст. наук). IA НАНУ Київ.

2 Івакін, В. (2008). Християнські поховальні пам'ятки, 199.

3 Мельник 0. Поховальні пам'ятки Києва, 113.

4 Панова, Т. (20๑4). Царство смерти. Погребальный обряд Средневековой Руси XI-XVI веков. Москва: Радуница, 68.

5 Мельник, 0. Поховальні пам'ятки Києва, 178.

6 Там само, 108.

7 Беляев, Л. (2005). Каменные «подушки» монашеских погребений и их ветхозаветный прототип. Российская археология,

$4,171$.

8 Макаров, Н. (1981). Каменные подушки в погребениях древнерусских городских некрополей. Советская археология, 2, 113.

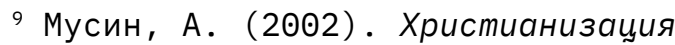
новгородской земли в IX-XIV веках. Погребальный обряд и христианские древности. Санкт-Петербург, 47.
Будівельні матеріали у поховальних конструкціях спорадично фіксують під час археологічних досліджень київських некрополів доби Середньовіччя та Модерну ${ }^{1}$. Зазвичай, вони трапляються in situ, як частина поховальної конструкції (плінфові, пірофілітові та мармурові саркофаги, поховання з повним або частковим огороджуванням небіжчика поховання на вимостках), додаткові елементи в облаштуванні могили (імітація «кам'яної подушки») та інколи випадково у заповненні поховальних споруд. Усі зафіксовані приклади стосуються індивідуальних поховальних споруд. Їх існуванню та розвитку, скоріш за все, посприяли вірування, згідно 3 якими потрібно було подбати про збереження людських решток, поховавши тіло ${ }^{2}$. Одна 3 таких форм збереження - влаштування поховальної конструкції у вигляді саркофагу. Матеріалами для виготовлення таких споруд слугували дерево, пірофілітовий сланець, плінфа та мармур, тому цей вид поховання був дорогим, і як наслідок - елітарним. У межах м. Києва лише 0,6 \% усіх відомих поховань - саркофаги ${ }^{3}$.

У конструкції певної кількості поховань було повне або часткове (біля голови, тулуба, ніг) огороджування небіжчика фрагментами будівельних матеріалів. Це можна пояснити тяжким матеріальним становищем покійника, коли за браком коштів на дерев'яну до- мовину почали використовувати будівельні матеріали для улаштування дна могильної ями. Деякі ж дослідники пов' язують цей вид поховальної конструкції 3 наслідуванням традиції поховань у саркофагах, коли, не маючи коштів, імітували цегляну гробницю за допомогою фрагментів плінфи чи цегли. Зауважимо, що такий тип облаштування могил не набув широкого поширення ні в Києві, ні в інших регіонах Східної Свропи ${ }^{4}$. Лише 0,5 \% поховань 3 огороджуванням прослідковується у межах м. Києва ${ }^{5}$.

Додатковими елементами в облаштуванні могили були кам'яні (плінфові, з вапняного розчину) подушки-підголівники ${ }^{6}$. Такий звичай на території давньоруської держави відомий з XI ст., і побутував він до XVII середини XVIII ст. Цей атрибут трапляється у похованнях як у дорослих індивідів (обох статей), так і дітей. Дослідники інтерпретують цю традицію по-різному, найчастіше пов'язують із чернецькими звичаями, де подушка була символом смирення плоті 7 й підкреслювала аскетичний образ життя ${ }^{8}$. Окрім цього, кам'яна подушка могла виконувати й утилітарну функцію - підтримання голови та надання небіжчику природного вигляду людини у стані сну ${ }^{9}$.

Майже всі перелічені випадки використання будівельних матеріалів у давньоруських поховальних комплексах археологічно 
10 Л[ебединцев], П. (1888). Спас на Берестове. Киевская Старина, 7, 11.

11 Івакін, Г. (2014). Про «Поховання Юрія Долгорукого» біля Спаса на Берестові. В Лаврський альманах: Києво-Печерська лавра в контек-

сті украӥнськоӥ історї̈ та культури: 36. наук. працьь (Вип. 29, спецвипуск Церква Спаса на Берестові, с. 133). Київ: Національний Києво-Печерський історико-культурний заповідник.

12 Тараненко, С., Мисько, Ю., \& Зажигалов, 0. (2019). Археологічна карта Науіонального Києво-Печерського історико-культурного заповідника. Київ: Національний Києво-Печерський історико-культурний заповідник, 172.

13 КПЛ-А-НДФ-384: Харламов, В., \& Гончар, В. (1990а). Отчет об археологических раскопках памятника архитектуры XII в. черкви Cпаса на Берестове, проведенных на территории Киево-Печерского государственного историкокультурного заповедника в 1989 г. Киев .

14 КПЛ-А-НДФ-689: Балакін, С. (2003). звіт про результати археологічного нагляду за виконанням шурфів у иеркві Cnаса на Берестові у $2 \odot \odot 2$ р. Київ.

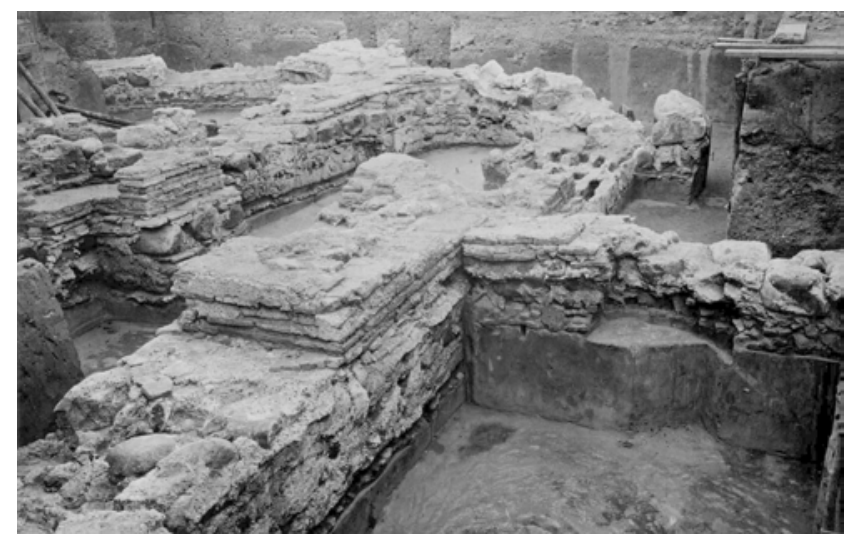

Рuc. 1. Ремонтно-реставраційні та археологічні дослідження 1909-1914 рр. (П. Покришкін)

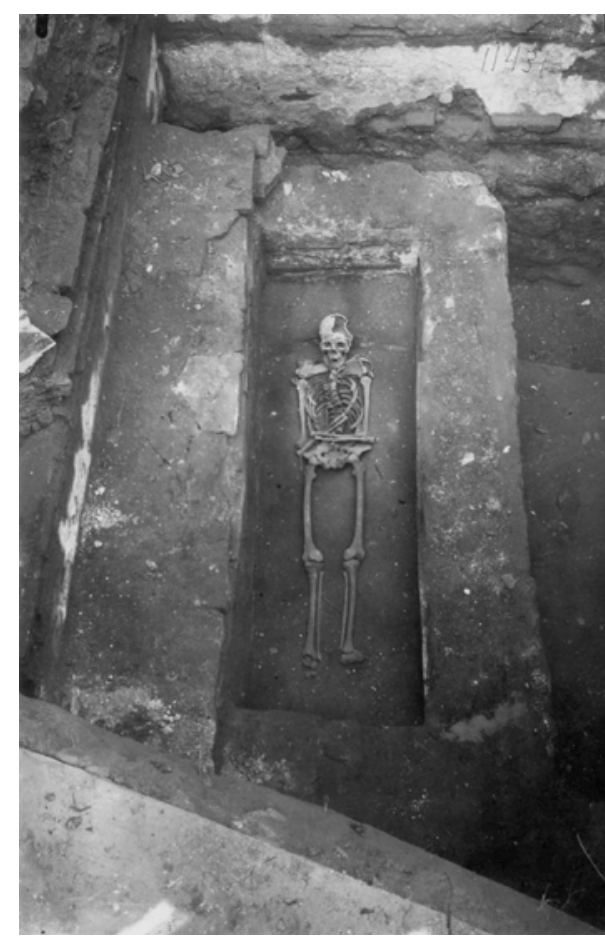

зафіксовано під час науково-рятівних досліджень некрополя церкви Спаса на Берестові у період 1914-2019 рр.

Перші поховання на території церкви було зафіксовано під час ремонту 18621865 рр. (П. Лебединцев) ${ }^{10}$ і реставраційних робіт 1909-1914 рр. (П. Покришкін) (рис. 1, 2) ${ }^{11}$. Наступні поховання виявлено: під час пошуків могили київського князя Юрія Долгорукого у 1947 р. (І. Самойловський) ${ }^{12}$, у результаті науково-рятівних розкопок 1989-1990 рр. (В. Харламов) (рис. 3, 4) ${ }^{13}$ та 2002-2003 рр. (Г. Івакін, С. Балакін) ${ }^{14}$.

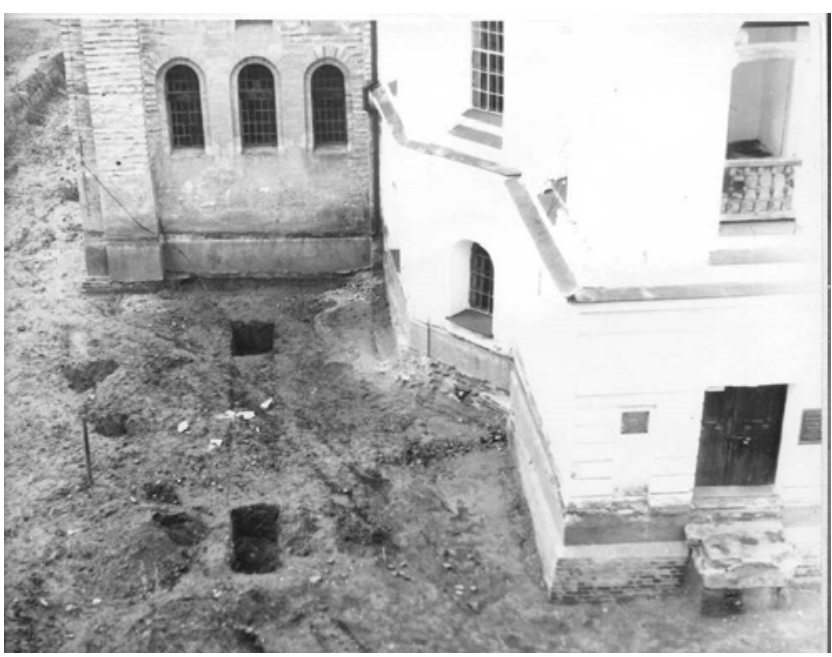

Рис. 3. Науково-рятівні розкопки 1989-1990 pp. (В. Харламов)
Рис. 2. Поховання. Ремонтно-реставраційні та археологічні дослідження 1909-1914 pp. (П. Покришкін) 


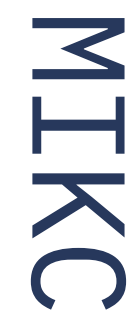

Рис. 4. Науково-рятівні розкопки 1989-1990 pр. (В. Харламов)

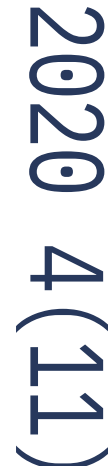

15 Харламов, В., \& Гончар, В. Отчет об археологических раскопках.

16 КПЛ-А-НДФ-385: Харламов, В. , \& Гончар, В. (1990b). Отчет об археологических исследованиях иеркви Спаса на Берестове XII-XIX вв., проведенных Архитектурно-археологической постоянно действующей экспедийей ИА АН УССР 8 1990 г. Киев.

17 Гончар, В. (2002). Середньовічний некрополь церкви Спаса на Берестові у Києві. В Церковная археология Южной Руси: междунар. конф. (с. 226).

Севастополь.

18 Балакін, С. Звіт про результати.

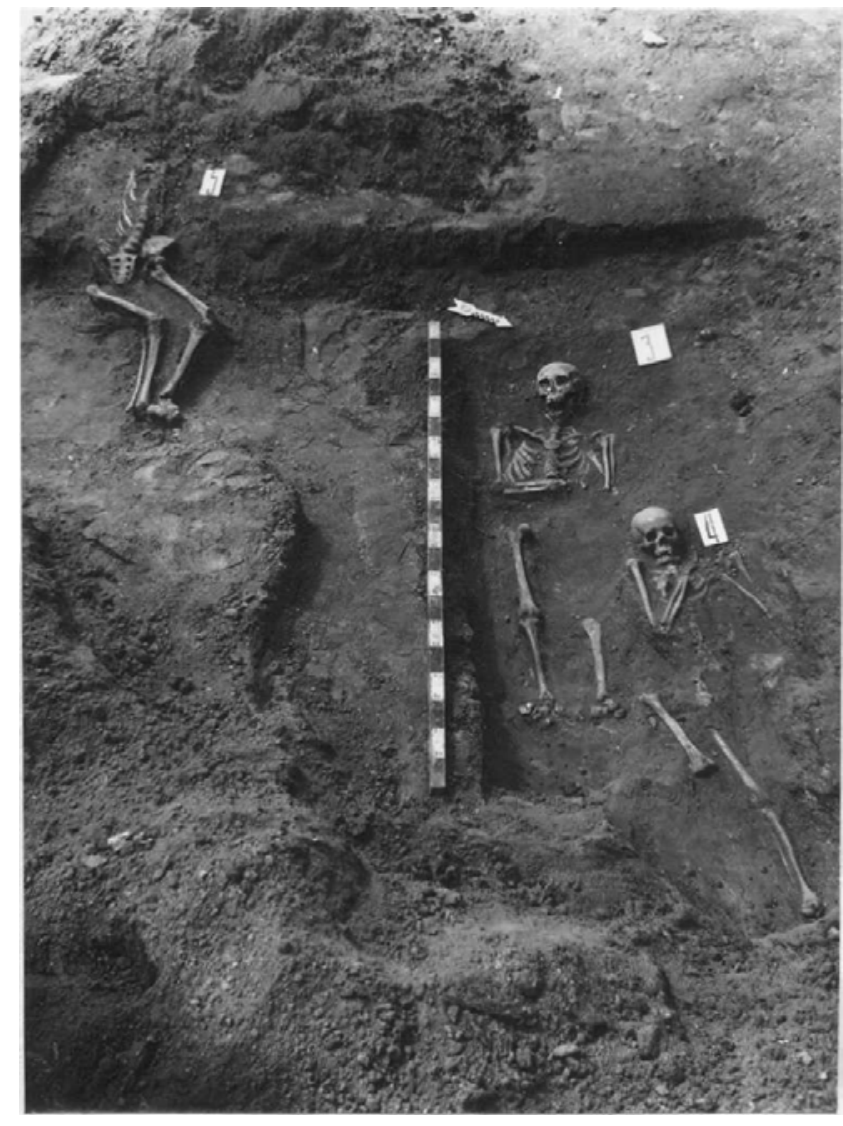

На сьогодні немає чіткої хронології функціонування Спаського некрополя. Першою згадкою про захоронення на цій території можна вважати рядки з Іпатіївського літопису, який повідомляє, що в 1138 р. «преставися Володимерьна Ефимья месяца априля в 4 день, в понеделник, порозное неделе», а Лаврентіївський літопис додає, що іiі поховали «на Берестовем оу святаго Спаса».
Поховання доньки Володимира Мономаха Євфимії найчастіше пов'язують зі склепом-саркофагом (саркофаг № 2 за В. Харламовим) із плінфи, знайденим у 1911-1914 pp. під час ремонтно-реставраційних та археологічних робіт під керівництвом П. П. Покришкіна та повторно дослідженим у 1990 p. (В. Харламов). Дослідник не залишив після себе ані польового щоденника, ані наукового звіту про результати своїх досліджень. Проте завдяки його повідомленню в «Известиях археологической комиссии» за 1911 р. до нас дійшли дані про знайдені кістяки численних поховань XVI-XVII ст.

Під час пошуку могили Ю. Долгорукого у 1947 р. усередині церкви було зафіксовано сім поховань, які за супровідним матеріалом продатовано XVII-XVIII ст.

У звіті 1989 р. В. Харламов фіксує «обширное кладбище XIV-XVII вв.» ${ }^{15}$. Проте вже у звіті 1990 рр. автор датує основний масив поховань (81 поховання) XVI-XVIII ст. ${ }^{16}$ Того ж року В. Харламов знайшов два пірофілітові саркофаги давньоруського часу ${ }^{17}$.

Серед антропологічного матеріалу, знайденого під час досліджень 2002-2003 рр., вирізняється жіночий кістяк XVII-XVIII ст., а також виявлено перевідкладені кістки близько 20 осіб ${ }^{18}$

Отже, перші захоронення на території Спаського монастиря можна віднести до 
Рuc. 5. Науково-рятівні дослідження 2018 2019 pp. (С. Тараненко, В. Івакін)

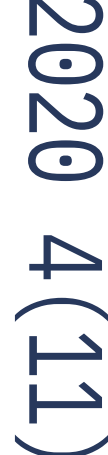

19 Мельник, 0. (2014). Цвинтар церкви Спаса на Берестові XIV-XVIII ст. В Лаврський альманах: Києво-Печерська лавра в контексті української історії та культури: 36. наук. праиь (Вип. 29, спецвипуск Церква Спаса на Берестові).

20 Тараненко, С., \& Івакін В. (2019). Некрополь иеркви Cпаса на Берестові. Матеріали Всеукраїнської наукової конференцї «Танатологія: смерть на навколо смерті у європейській культу рі». Київ, 52-56.

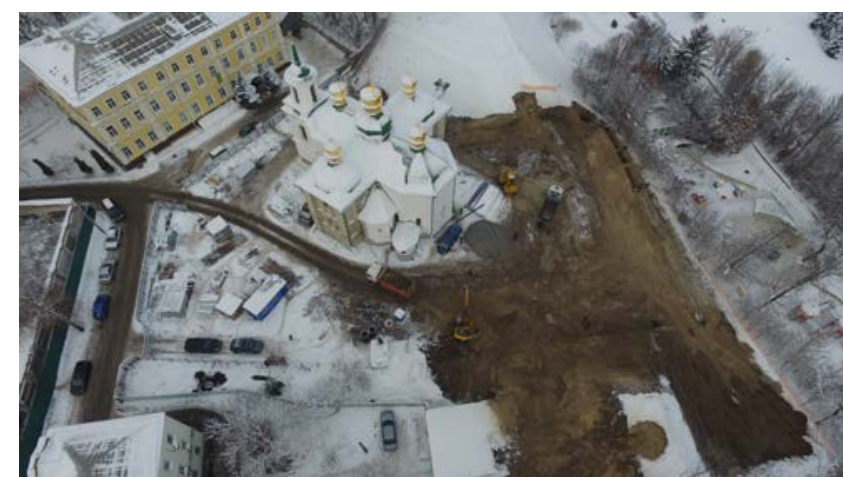

Puс. 6. Робочі моменти розчистка поховання 332 (2019 р.)

XII ст. Періодично поховання відбувалися на цій території у XIV-XVI ст. Проте безпосередній розвиток Спаського некрополя тривав у XVII-XVIII ст. до заборони 1772 р. на поховання у межах міста ${ }^{19}$.

У 2018-2019 рр. науково-дослідний сектор археології Національного Києво-Печерського історико-культурного заповідника та архітектурно-археологічна експедиція Інституту археології Національної академії наук України (С. Тараненко, В. Івакін) проводили науково-рятувальні дослідження на території церкви Спаса на Берестові (рис. 5). Під час досліджень було виявлено 431 поховальний комплекс різного ступеня збереження (рис. 6) ${ }^{20}$. Серед них: $67 \%$ поховань зафіксовано у дерев'яній труні, $30 \%-$ у могильній ямі, 1 \% - (1 од.) частково огороджених,

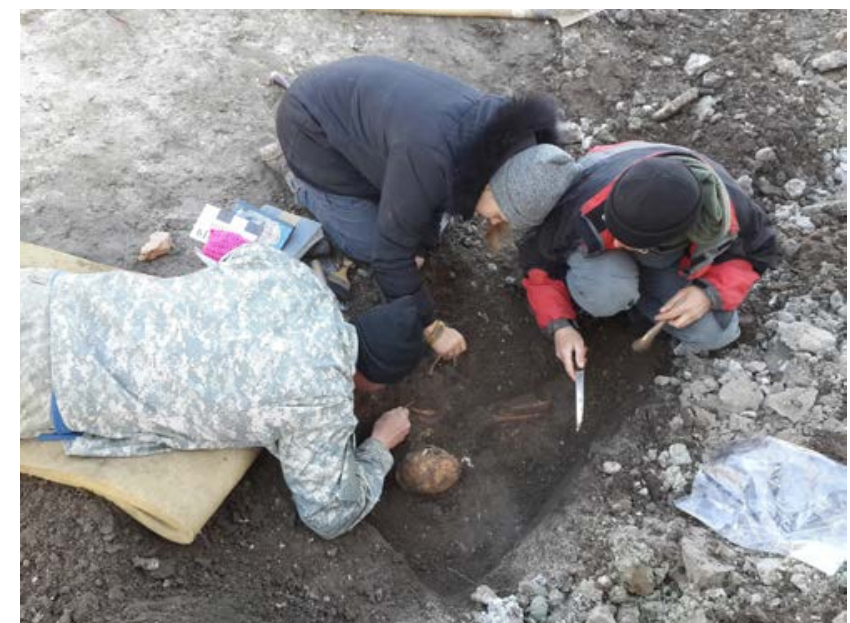

$1 \%$ (2 од.) - із повним огородженням, $1 \%$ (3 од.) - із кам'яним підголівником (рис. 7). Вперше за історію досліджень на цій території у конструкціях поховань доби Модерну було зафіксовано фрагменти давньоруських будівельних матеріалів вторинного використання, що містили залишки вапняно-цем'янкового розчину, та набір технологічних ознак,

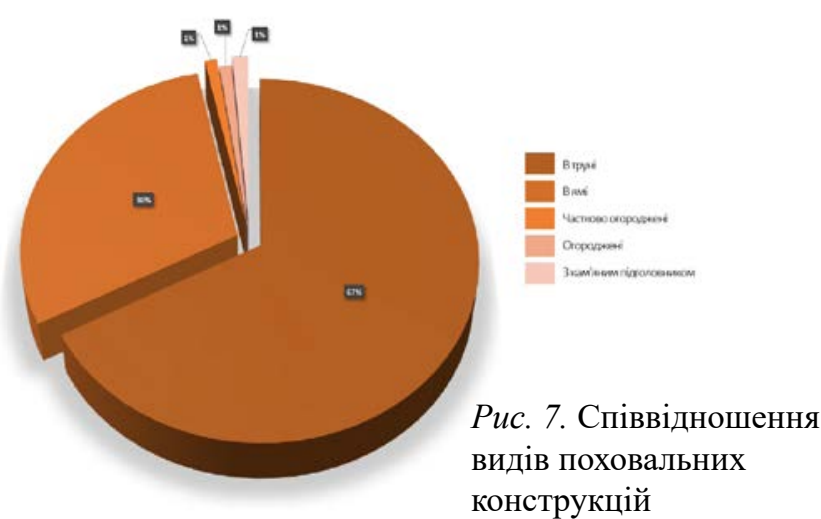




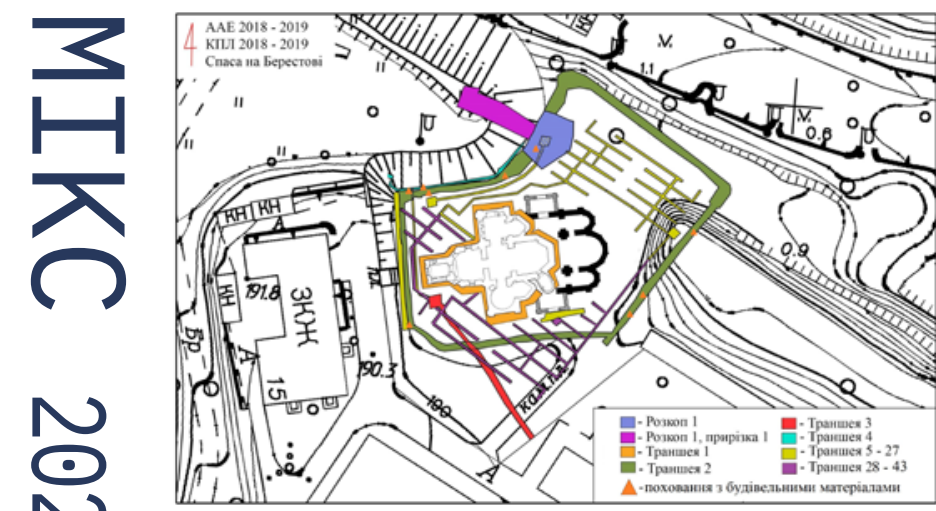

Рис. 8. План-схема розташування поховань iз давньоруськими будівельними матеріалами

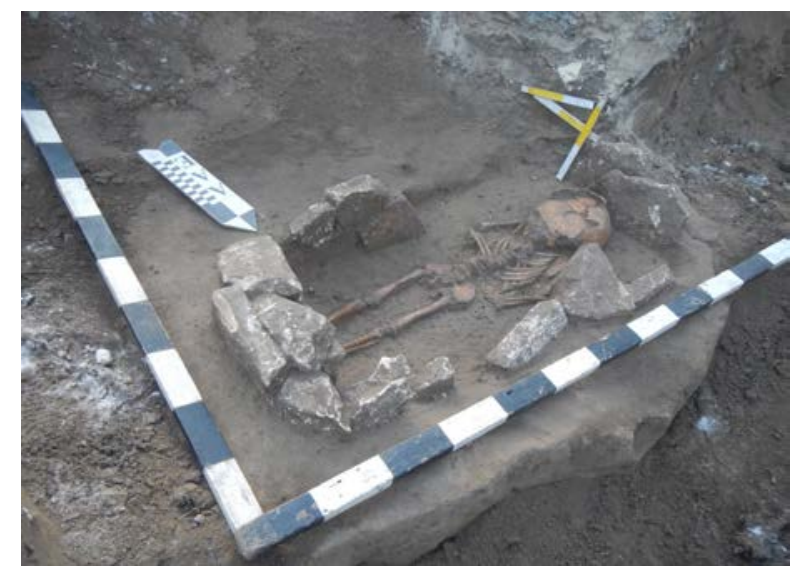

Puc. 9. Поховання 50 (2019 р.) притаманних основному об'єму давньоруського храму. Плінфу (усього 59 одиниць) зафіксовано у похованнях $24,30,37,50,78,82$, 84, 168 та 226 (таблиця, рис. 8). За глибиною залягання та стратиграфією їх датують XVI XVIII ст. Серед поховань можна виокремити декілька видів конструкцій із будівельними матеріалами: повне огородження небіжчика (поховання 50), повне огородження 3 додатковим елементом в облаштуванні могили у вигляді кам' яної подушки (далі - 3 кам'яною подушкою) (поховання 24), часткове огородження (голова) з кам'яною подушкою (по- ховання 84), дерев'яна домовина з кам'яною подушкою (поховання 168), дерев'яна труна, заповнена фрагментами пірофілітового сланцю (поховання 78), плити пірофілітового сланцю у ногах та голові (поховання 82), у заповненні поховальної ями (поховання 30 , 37, 226).

Поховання 50 (рис. 9). Дитина, 2-3 роки: фрагменти ребер і хребців, стегнові кістки, великі гомілкові кістки, малі гомілкові кістки, ліва сіднична кістка, права лобкова кістка. Дитяче поховання здійснене у могильній ямі без слідів деревини від труни, орієнто-

\section{Кількість плінфи у межах одного поховання}

\begin{tabular}{|l|c|l|}
\hline Поховання & Кількість (од.) & \multicolumn{1}{|c|}{ Інвентарні № } \\
\hline 24 & 16 & $\begin{array}{l}\text { № 3006, 3008, 3010, 3012, 3023, 3033, 3078-3080, 3081-3083, } \\
\text { 3086, 3087, 3090, 3091 }\end{array}$ \\
\hline 30 & 20 & № 3024, 3025, 3026, 3031, 3042-3057 \\
\hline 37 & 1 & № 3070 \\
\hline 50 & 12 & $\begin{array}{l}\text { №3003, 3009, 3015, 3016, 3019, 3022, 3037, 3077, 3084, 3095, } \\
\text { 3103, 3106 }\end{array}$ \\
\hline 78 & 2 & № 3032, 3067 \\
\hline 84 & 4 & № 3041, 3115, 3118, 3122 \\
\hline 168 & 2 & № 3035, 3066 \\
\hline 226 & 2 & № 3030, 3034 \\
\hline
\end{tabular}


Товщина та колір плінфи 3 поховань

\begin{tabular}{|c|c|c|c|}
\hline $\begin{array}{l}\text { Товщина } \\
\text { (см) }\end{array}$ & $\begin{array}{l}\text { Кількість } \\
\text { (одн.) }\end{array}$ & Колір & $\begin{array}{l}\text { Кількість } \\
\text { (од.) }\end{array}$ \\
\hline 3,2 & 1 & Жовтий & 3 \\
\hline 3,4 & 1 & Брудно-жовтий & 3 \\
\hline 3,5 & 2 & Бежевий & 4 \\
\hline 3,6 & 1 & Брудно-бежевий & 16 \\
\hline 3,8 & 1 & Персиковий & 6 \\
\hline 3,9 & 4 & Брудно-персиковий & 12 \\
\hline 4,0 & 3 & Теракотовий & 2 \\
\hline 4,1 & 5 & Брудно-теракотовий & 4 \\
\hline 4,2 & 7 & Темно-коричневий & 1 \\
\hline 4,3 & 10 & Рожевий & 2 \\
\hline 4,4 & 2 & Брудно-рожевий & 1 \\
\hline 4,5 & 4 & Сірий & 1 \\
\hline
\end{tabular}

\begin{tabular}{|l|l|}
\hline 4,6 & 6 \\
\hline 4,7 & 1 \\
\hline 4,8 & 2 \\
\hline 4,9 & 1 \\
\hline 5,0 & 3 \\
\hline 5,2 & 1 \\
\hline 5,3 & 1 \\
\hline 5,4 & 1 \\
\hline 5,7 & 1 \\
\hline 5,8 & 1 \\
\hline
\end{tabular}




\section{Технологічні ознаки}

\begin{tabular}{|c|l|c|}
\hline \multicolumn{1}{|c|}{ № } & \multicolumn{1}{|c|}{ Назва } & $\begin{array}{c}\text { Кількість } \\
\text { (од.) }\end{array}$ \\
\hline Всього 59 од. 3 них на: & 19 \\
\hline 1 & Закраїни після зняття плінфи з нерозбірної форми & 21 \\
\hline 2 & Мікросліди від протягування правила & 38 \\
\hline 3 & Ознаки формування у нерозбірній формі & 48 \\
\hline 4 & Ознаки формування у формі без дна & 6 \\
\hline 5 & Сліди зрізу закраїн та затікань під форму & 9 \\
\hline 6 & Запливи під форму & 2 \\
\hline 7 & Сліди від формувальної коробки & 26 \\
\hline 8 & Сліди дощу & 3 \\
\hline 9 & Підсипка піском & 6 \\
\hline 10 & Напливні бортики & 26 \\
\hline 11 & Вкрита шаром вапняно-цем’янкового розчину & \\
\hline
\end{tabular}

ване головою на захід. По контуру й на дні орієнтоване головою на захід у поховальній могильну яму обкладено фрагментами плінфи вторинного використання (усього 12 одиниць). Товщина плінфи коливається у межах від 3,2 до 5,0 см. Створено у формі без дна 3 підсипкою піском, у нерозбірній формі, з закраїнами та мікрослідами від протягування правила.

ямі. По контуру та на дні могильну яму обкладено фрагментами плінфи вторинного використання. Над головою та під нею розміщувалися дві цілі плінфи. Усього у похованні зафіксовано 16 зразків будівельних матеріалів із залишками розчину. Товщина плінфи коливається у межах від 3,5 до 5,4 см.

Поховання 24 (рис. 10, 11). Чоловік, У формі без дна з підсипкою піском, у не25-35 років: череп, шийні хребці, ключиці, розбірній формі, з закраїнами та мікрослідаплечові кістки. Поховання здійснене у мо- ми від протягування правила. 


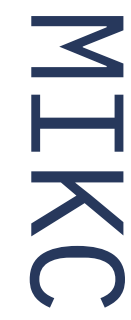

(3)

Pис. 10. Поховання 24 (2019 р.)

Рис. 11. Поховання 24 (2019 р.)

Рис. 12. Поховання 84 (2019 р.)

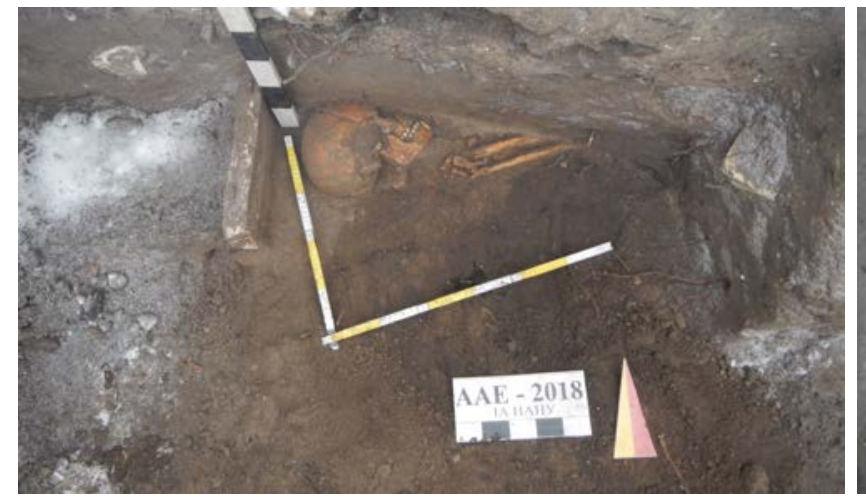

Поховання 84 (рис. 12). Чоловік, 25-35 років: череп, нижня щелепа, шийні хребці, фрагменти ребер і хребців, ключиці, плечові кістки. Поховання здійснене у могильній ямі без слідів деревини від труни, орієнтоване головою на захід у поховальній ямі. Поховальна конструкція складна: на дні по контуру ями голову кістяка обкладено фрагментами плінфи вторинного використання. Під головою - фрагмент лекальної

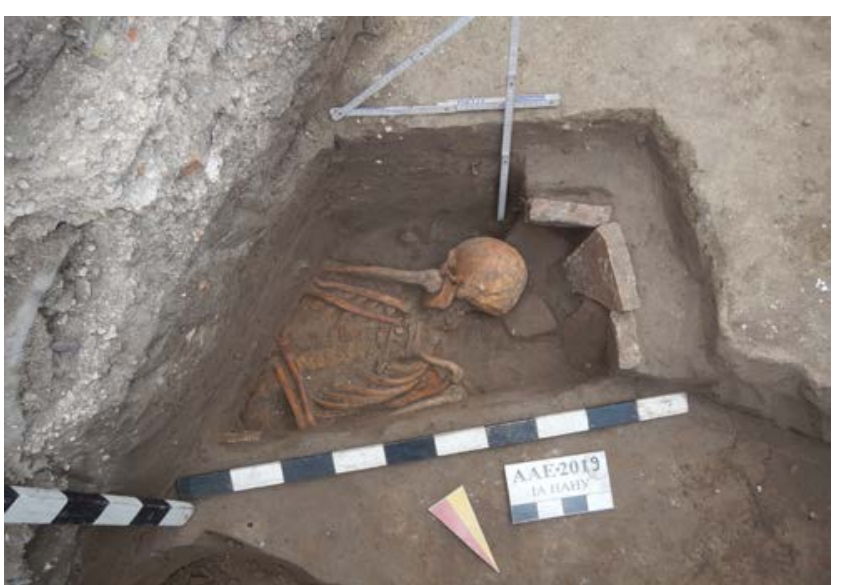

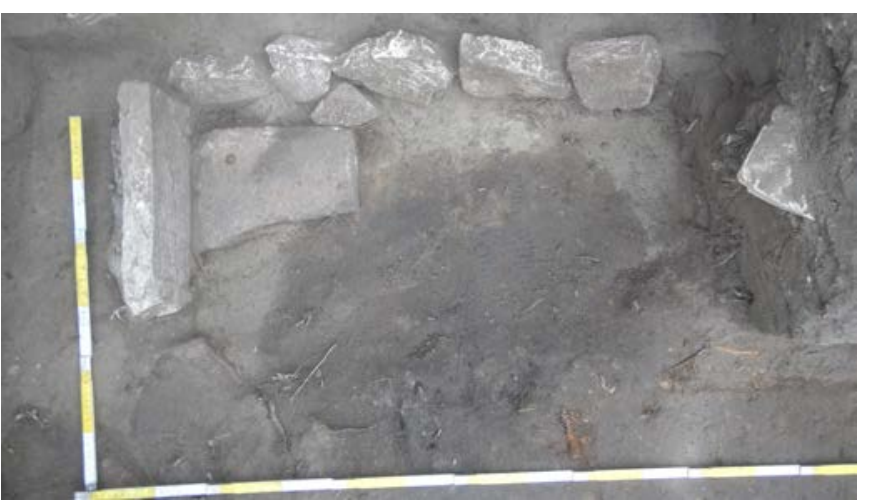

плінфи. Слідів деревини від домовини виявити не вдалося, проте чітко зафіксовано дошку/дерев'яну підстилку, на якій лежав небіжчик. Усього зафіксовано 4 плінфи. Товщина від 4,0 до 5,3 см. Серед технологічних ознак - закраїни, мікросліди від зняття надлишку глини, нерозбірна формна без дна.

Поховання 168 (рис. 13). Жінка, 2030 років: нижня щелепа з зубами, грудина, обидві ключиці, плечові, ліктьові, променеві,

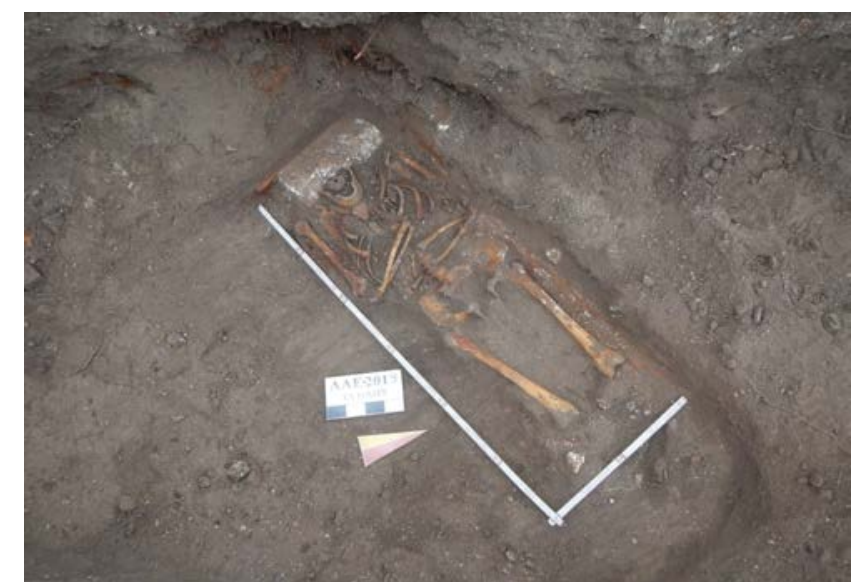




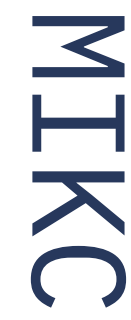

 стегнові кістки та деякі фаланги лівої верхньої кінцівки. Частково збереглися кістки тазу та хребтовий стовп. Поховання здійснене у дерев'яній домовині, орієнтоване головою на південний захід. Під головою кістяка була плінфа (№ 3035), ще одну виявлено у заповненні поховальної ями (№ 3036). Плінфу з-під голови було сформовано у нерозбірній формі без дна на пісочній підсипці, вона мала затікання під форму та закраїни після зняття 3 форми. Ї̈̈ товщина дорівнює $4,0 \mathrm{~cm}$, керамічне тісто мало персиковий колір. Другий примірник мав аналогічні технологічні ознаки, товщина $-4,5 \mathrm{~cm}$.

Поховання 78 (рис. 14). Репрезентативність кісток дуже погана. Дві скроневі кістки, фрагмент нижньої щелепи (без гілок), діафізи великих гомілкових кісток. Вік і стать визначити складно. Дерев'яна

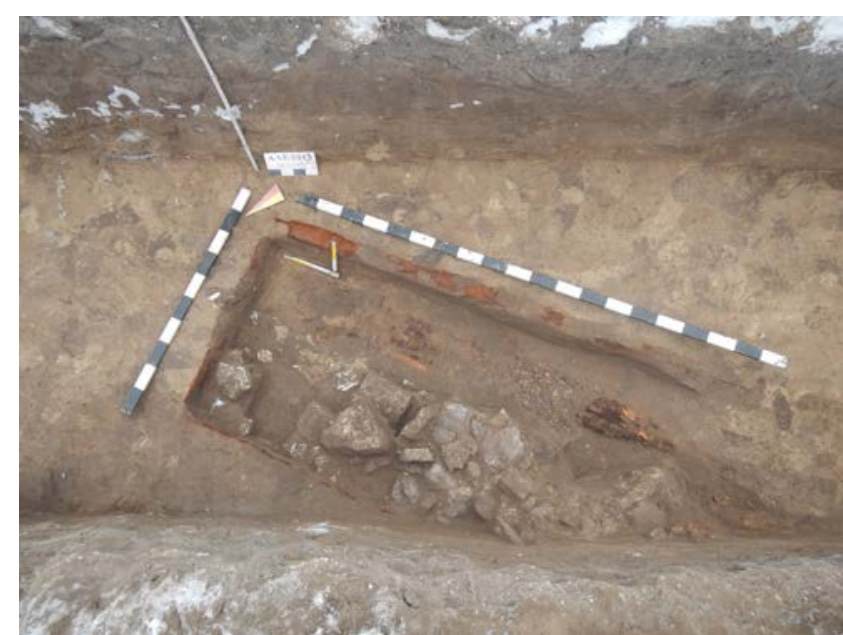

труна заповнена фрагментами пірофілітового сланцю та двома фрагментами плінфи (№ 3032, 3067). № 3032 має товщину 4,3 cм, a № $3066-5,8$ см. Зразки створені у нерозбірній формі без дна.

Поховання 82 (рис. 15). Чоловік, 25-35 років: кістяк збережений без втрат Поховання здійснене у дерев'яній домовині, орієнтоване головою на захід. Поруч із головою (над нею у вертикальному положенні) та у ногах (ступні вертикально спиралися на плиту) було зафіксовано дві плити пірофілітового сланцю фіолетово-червоного кольору. Фрагмент над головою мав розміри 0,7 $\times 0,25 \mathrm{м}$, товщина -6 см. Чітка прямокутна форма, рівність торців, однакова товщина та відносна гладкість поверхі вказує на те, що iї обробили спеціально. Фрагмент плити під ногами мав розміри $0,5 \times 0,2$ м, товщина -

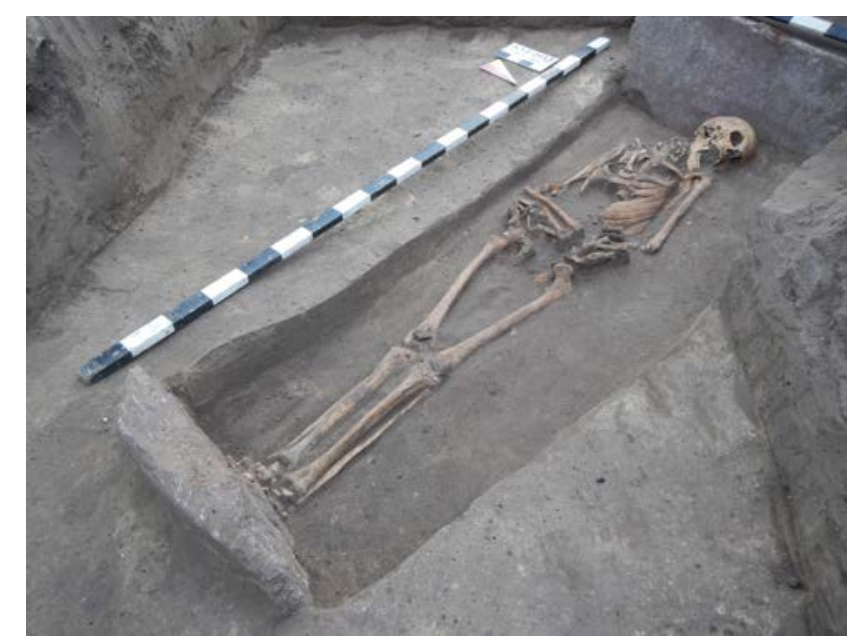

Рис. 14. Поховання 78 (2019 р.) Рис. 15. Поховання 82 (2019 р.) 
${ }_{21}$ Ёлшин, Д. (2017). Киевская плинфа X-XIII вв.: опыт типологии. В Культурний шар. Статmі на пошану Гліба Юрійовича Івакіна (с. 108). Київ: Laurus.
0,15 м. Форма - аморфна, не оброблена. На відміну від пірофілітових саркофагів, на цих плитах не було заглиблень для пазів і слідів від скріплення металевими скобами. Зверху над похованим була масивна дерев'яна дошка, яка слугувала накриттям для цього «псевдосаркофагу». Видобуток пірофілітового сланцю для будівельних та поховальних потреб припинили після 1240 р. Найімовірніше, ці плити використовували за їхнім початковим призначенням у давньоруську добу, а у XVII-XVIII ст. - повторно у цьому захороненні. Однак можна припустити, що ці плити слугували однією з форм архітектурних елементів церкви у цей самий час.

Поховання 30. Щонайменше два індивіди: основне - дитини, від якої залишилися тільки фрагменти черепа, та перевідкладене - жінки 30-40 років (ліва ключиця, фрагменти ребер, велика ліва гомілкова кістка). Антропологічний матеріал виявлено в одному заповненні з численними фрагментами плінфи. У заповненні поховальної ями знайдено 20 фрагментів плінфи (№ 3024, 3025, $3026,3031,3042-3057$ ) від 3,9 до 4,8 см завтовшки. Плінфа має ознаки типу III.II: створено у формі без дна з підсипкою піском, у нерозбірній формі, з закраїнами та мікрослідами від протягування правила, трапляються сліди зрізування закраїн і затікань під форму.
Поховання 37. Також перевідкладене, збереглися тільки фрагменти гомілкових кісток. У заповненні поховальної ями виявлено фрагмент округлої лекальної плінфи № 3070 , товщина $-4,8$ см. Закраїни після зняття плінфи з нерозбірної форми, запливи під форму, ознаки створення у нерозбірній формі, ознаки створення у формі без дна.

Поховання 226 зафіксовано у перевідкладеному стані. У заповненні могильної ями виявлено дві плінфи - № 3030, 3034, 3,9 i 4,0 см завтовшки відповідно. Зразки мають ознаки типу III.II: створені у нерозбірній формі без дна на пісочній підсипці та мали затікання під форму.

Як ми бачимо, зразки плінфи у вищенаведених поховальних комплексах мають ознаки типу III.II (типологія Д. Йолшина) ${ }^{21}$ : створення у нерозбірній формі без дна з підсипкою піском, із закраїнами та мікрослідами від протягування правила. Усі ці ознаки датують плінфу у межах м. Києва кінцем XI - початком XII ст., що відповідає академічному погляду на час зведення церкви Спаса на Берестові. Аналіз будівельного матеріалу у цих конструкціях надає важливий інформативний матеріал для реконструкції поховальних споруд пізньосередньовічного часу та доби Модерну з вторинним використанням давньоруських будівельних матері- 
алів. Характерним видається продовження давньоруської чернецької традиції підкладання плінфи як «подушки-підголівника», як підтвердження християнського аскетизму.

Фіксування давньоруських будівельних матеріалів надає додаткові дані для реконструкції існування церкви Спаса на Берестові у період з 1240 по 1640 pp. За усталеною історіографією відомо, що церкву, найпевніше, було зруйновано у 1240 р. під час нападу на місто хана Батия. На сьогодні існують непрямі дані про ремонт церкви у XV ст. за князювання родини Олельковичів - датування декількох поховань XV ст. під час досліджень В. Харламова у 1989-1990рр.

\section{References}

Beljaev, L. (2005). Kamennye "podushki" monasheskih pogrebenij $\mathrm{i}$ ih vethozavetnyj prototip. Rossijskaja arheologija, 4, 171 [in Russian].

Honchar, V. (2002). Serednovichnyi nekropol tserkvy Spasa na Berestovi u Kyievi. In Cerkovnaja arheologija Juzhnoj Rusi: mezhdunar. konf. (p. 226). Sevastopol [in Ukrainian].

Ivakin, G. (2014). Pro "Pokhovannia Yuriia Dolhorukoho" bilia Spasa na Berestovi. In Lavrskyi almanakh: Kyievo-Pecherska lavra v konteksti ukrainskoi istorii ta kultury (Vol. 29, p. 133). Kyiv: Natsionalnyi Kyievo-Pecherskyi istoryko-kulturnyi zapovidnyk [in Ukrainian].

Ivakin, V. (2008). Khrystyianski pokhovalni pam 'iatky davnoruskoho Kyieva. Kyiv: KIT [in Ukrainian].
Вочевидь до другої половини XVII ст. (часу відбудови церкви Петром Могилою) будівельні матеріали давньоруського храму, який і далі руйнувався, активно привласнювало місцеве населення для своїх потреб. Однак під час великої відбудови значну частину давньоруських будівельних матеріалів, передусім цілі форми, було використано для формування нового об'єму храму. Не затребувані у «великому ремонті» фрагменти плінфи сформували культурний шар навколо церкви. Імовірно, саме їх почали використовувати у поховальних конструкціях, про які йдеться у цій статті.

Jolshin, D. (2017). Kievskaja plinfa X-XIII vv.: opyt tipologii. In Kulturnyi shar. Statti na poshanu Hliba Yuriiovycha Ivakina (p. 108). Kyiv: Laurus [in Russian].

KPL-A-NDF-384: Harlamov, V., \& Gonchar, V. (1990a). Otchet ob arheologicheskih raskopkah pamjatnika arhitektury XII v. cerkvi Spasa na Berestove, provedennyh na territorii Kievo-Pecherskogo gosudarstvennogo istoriko-kul'turnogo zapovednika v $1989 \mathrm{~g}$. Kiev [in Russian].

KPL-A-NDF-385: Harlamov, V., \& Gonchar, V. (1990b). Otchet ob arheologicheskih issledovanijah cerkvi Spasa na Berestove XII-XIX vv, provedennyh Arhitekturno-arheologicheskoj postojanno dejstvujushhej jekspediciej IA AN USSR v $1990 \mathrm{~g}$. Kiev [in Russian]. 
KPL-A-NDF-689: Balakin, S. (2003). Zvit pro rezultaty arkheolohichnoho nahliadu za vykonanniam shurfiv u tserkvi Spasa na Berestovi u 2002 r. Kyiv [in Ukrainian].

L[ebedincev], P. (1888). Spas na Berestove. Kievskaja Starina, 7, 11 [in Russian]

Makarov, N. (1981). Kamennye podushki v pogrebenijah drevnerusskih gorodskih nekropolej Sovetskaja arheologija, 2, 113 [in Russian].

Melnyk, O. (2014). Tsvyntar tserkvy Spasa na Berestovi XIV-XVIII st. In Lavrskyi almanakh: Kyievo-Pecherska lavra v konteksti ukrainskoi istorii ta kultury (Vol. 29) [in Ukrainian].

Melnyk O. (2017). Pokhovalni pam'iatky Kyieva XVI-XVIII st. (Master's thesis). IA NANU, Kyiv [in Ukrainian].
Musin, A. (2002). Hristianizacija novgorodskoj zemli v IX-XIV vekah. Pogrebal'nyj obrjad i hristianskie drevnosti. Sankt-Peterburg [in Russian]

Panova T. (2004). Carstvo smerti. Pogrebal'nyj obrjad Srednevekovoj Rusi XI-XVI vekov. Moskva: Radunica [in Russian].

Taranenko, S., \& Ivakin, V. (2019). Nekropol tserkvy Spasa na Berestovi. Materialy Vseukrainskoi naukovoi konferentsii "Tanatolohiia: smert na navkolo smerti u yevropeiskii kulturi”. Kyiv [in Ukrainian]

Taranenko, S., Mysko, Yu., \& Zazhyhalov, O. (2019). Arkheolohichna karta Natsionalnoho Kyievo-Pecherskoho istoryko-kulturnoho zapovidnyka. Kyiv: Natsionalnyi Kyievo-Pecherskyi istoryko-kulturnyi zapovidnyk [in Ukrainian].

\section{Olena Makhota}

\section{OLD RUS BUILDING MATERIALS IN BURIAL COMPLEXES OF THE XVII-XIX CENTURIES NECROPOLIS OF THE SAVIOR IN BERESTOVE (ACCORDING TO RESEARCH MATERIALS 2018-2019)}

The article considers the process of using ancient Rus building materials in burial structures of the Modern Age in the necropolis of the Church of the Savior in Brestove. The main periods of researches of the Spas necropolis from 1862 to 2019 are analyzed. According to scientific reports, we are selected data on burials of the XII-XIX centuries, which contained ancient Rus building materials: plinth and slabs of pyrophyllite shale. The main attention is focused on the information obtained during the research and rescue research in 2018-2019, where we are recorded nine burials (XVII-XIX centuries) with partial or complete fencing with ancient Russ building materials. Today, building materials of the Old Rus period on the territory of the Spas necropolis are found in the form of part of the burial structure, additional elements in the arrangement of the tomb and in the filling of burial structures. 
Collected and processed set of materials provides additional data for the reconstruction of historical events associated with the decline and reconstruction of the church. The fixation of such burial structures, in turn, also provides indirect data on the traditions of the funeral rite of the inhabitants of Pechersk town and the military of the Kiev fortress in the XVII-XIX centuries. - parishioners of the Church of the Savior in Berestove.

Keywords: burial structure, building materials, plinth, necropolis, Church of the Savior on Berestove, Modern Age. 